\title{
Editorial: Festschrift for Professor Emeritus Jørgen Delman
}

\author{
BENT NIELSEN, TRINE BROX AND VERA SKVIRSKAJA
}

This issue of the Copenhagen Journal of Asian Studies is a festschrift in honour of Dr. Jørgen Delman, Professor Emeritus of China Studies at the Department of Cross-Cultural and Regional Studies, University of Copenhagen. We present a small collection of vignettes and research articles from among the many friends and colleagues he worked closely with and significantly impacted. As a person who is immensely generous with his time, knowledge, experience and network, Delman has been instrumental to the development of China Studies in Denmark. His relationship with China has been life-long. He has lived and worked there for extended periods (1977-78, 1983-86 and 1991-96), and since 1982, he visited the country at least once a year with the exceptions of 2003 (when he instead travelled to Vietnam) and 2020-21 (when China closed its borders due to the Covid-19 pandemic).

Delman's (b. 1950) academic interaction with China took off in the early 1970s and spanned nearly half a century. Originally, Delman studied English language and literature at Aarhus University (BA in 1972). He decided, however, to switch to China Studies, and what followed was (and is) an impressive academic and professional career. Having finished his MA at the Institute of East Asian Studies, Aarhus University, Delman continued his studies of modern China at Peking University in 1977-78. Returning to Denmark in 1978, Delman worked for a few years as a free-lance journalist, teacher of Chinese language and co-manager of the China Information Service until 1983, when he joined the ranks of professionals: his first assignment was as the Programme Officer of the project portfolio of the Food and Agriculture Organization of the United Nations in China. He was in charge of the day-to-day business supervising 18 employees and in close contact with the Chinese institutions and government agencies, which gave him invaluable work experience with local authorities in China.

This article can be accessed at https:/ / doi.org/10.22439/ cjas.v39i2.6386. 
Consequently, Delman became a valued consultant for Danish businesses attempting to break into the Chinese market, but he also had a wish to return to academia, which brought him back to his alma mater at the end of the 1980s.

Grants from the Danish Council for Development Research secured Delman a position as a research fellow at the Institute of East Asian Studies, Aarhus University, where his studies of foreign projects and modernisation of agriculture in China resulted in the PhD dissertation Agricultural Extension in Renshou County, China: A Case-study of Bureaucratic Intervention for Agricultural Innovation and Change (1991). Armed with these academic credentials, Delman joined the Danish company Ramboll as a Senior Consultant (1991-98) and ultimately as Head of Department for Private Sector and SME Development (1998-2001). While project management and institutional and human resource development were at the core of Delman's career at Ramboll, he was also deeply involved in the preparation and management of the ChinaEU Centre for Agricultural Technology. During the latter half of this period, Delman was stationed in Denmark but travelled extensively all over the world (India, Mongolia, Russia, Malawi, Mozambique, Tanzania, Peru, to mention a few countries, in addition to the EU).

In the early 2000s, Delman returned to academia, first as the director of the Nordic Institute of Asian Studies (NIAS, 2002-2009) and then as a professor of China Studies at the Department of Cross-Cultural and Regional Studies (CCRS), University of Copenhagen (UCPH, 20092021). During his tenure at NIAS, some of Delman's main accomplishments include the development of a new Nordic partnership, a new strategy and financing plan and the restructuring of NIAS ownership so it became an independent, Nordic research institute attached to the UCPH. His own research has focused on several topics, such as business and politics in China and Vietnam, the transformation of the political system in China, China's new role in Africa and China's energy strategy. More recently, Delman's research interests have included climate governance and the Belt and Road Initiative, and he has established himself as an international expert in Chinese local and global politics, China's climate policies and China's new international initiatives.

At CCRS, Delman's unique combination of professional experience with project management and his academic training revitalised the field of Asian Studies in general and China Studies in particular. Delman has been a tremendous asset to China Studies, and his 
generosity and outstanding mentoring abilities defined his relations with students, young scholars and colleagues. The fact that many of his publications are co-authored with students or colleagues shows how Delman's approach to academia has been guided by values of inclusiveness and cooperation. Also, a significant number of his publications are co-authored with Chinese experts in the field, and he has published in Chinese.

Delman's organisational and administrative efforts and achievements in support of China studies have been far beyond the call of duty. He coordinated a number of language training programmes (e.g. with the European Centre for Chinese Studies, Peking University and Zhejiang University, 2009-14) and was a member of the Asian Dynamics Initiative Academic Panel (from 2009). In 2013, Delman co-established the UCPH think tank on China (ThinkChina.dk), where he still serves as a member of the Advisory Group and an academic coordinator, which has been an important step forward in cross-disciplinary approaches to the study of China at the UCPH. Since he retired in 2021, Delman has continued his engagement with China, making an impact on academic circles in Denmark and abroad.

Recently, Delman (2021: 18) has summed up eight (lucky number!) points regarding what his experiences with China have taught him. These eight points give the reader an excellent insight into his understanding of China and, maybe more importantly, his view of how Europeans should prepare themselves for a world in which China will play an increasingly significant role. He wrote:

1. You don't understand China if you don't understand rural China.

2. You don't understand China if you don't understand the Chinese bureaucracy, i.e., the system of the party-state.

3. China's Communist Party has shown itself to be capable of providing the country with beneficial and popular changes without the party itself changing.

4. China's fantastic development over the last four decades has been driven by entrepreneurship and innovation, often through cooperation between private and state operators, including academics.

5. You don't understand China if you don't have good Chinese friends.

6. Prudent and pragmatic relations with China are essential for the future of Denmark. However, this poses great challenges, because we recognise different political, cultural and ethical positions. 
7. We need a critical mass of professionals in Denmark who speak Chinese and who understand China's cultural codes in order to manoeuvre efficiently in China.

8. Finally, a China scholar needs a family that appreciates China.

Delman has had a broad interest in, and appreciation of, everything Chinese, and this festschrift similarly presents a selection of Chinarelated topics that highlight the breadth of his interests in China, past and present. The articles and vignettes in this volume are invited contributions by former colleagues of Delman in Denmark. We start with an article by Camilla T. N. Sørensen, a mentee and former colleague of Delman at NIAS in Copenhagen. Bridging the research fields of international relations, comparative politics and area studies, she analyses the main driving forces in Chinese foreign policy, while developing a neoclassical realist argument on the foreign policy of rising authoritarian states. The contribution by Kjeld Erik Brødsgaard and Kasper Ingeman Beck at the Copenhagen Business School takes us to the research field of economics and politics with a study of cadre management. They argue that Chinese business leaders form a vital recruitment base for leadership renewal, and that the rotation between big business and the political world constitutes the main unifying and stabilising factor in the Chinese political system. The article by Chunrong Liu and Yanwen Tang analyses the Party-society nexus in post-reform China characterised by rapid market transition and globalisation processes in order to shed light on the Party's resilience.

In addition to the research articles, we have invited vignettes from contributing authors to share their reflections on China. The first is by Anne Wedell-Wedellsborg, fellow-student, colleague and lifelong friend of Delman since the early days of Modern China Studies at Aarhus University. Her contribution deals with the research field of literature, specifically the reception of a novel written by Yu Hua in 1991. The novel was reviewed twice by the same critic, but fifteen years apart, allowing us to experience how his views shifted according to a China in transition. Stig Thøgersen, who was Delman's China Studies classmate at Aarhus University in the 1970s, and who later collaborated with Delman on research projects, has written about the history of rural education in China, introducing the debate of whether rural China should train farmers or educate citizens. The third vignette is written by Mikkel Bunkenborg, an anthropologist and former colleague at China Studies, University of Copenhagen. His vignette is based on 
an ethnographic study of the Chinese mining enclaves in Mongolia, reflecting upon anthropological and 'post-colonial' misconceptions about the practices of gardening in these enclaves.

We at the CJAS dedicate this issue to the research on China as a modest token of gratitude for Delman's continuous support and encouragement. When in 2019 the fate of the journal was far from clear and its affiliation with the University of Copenhagen was far from certain, he was one of the few enthusiastic supporters of the journal's return to the UCPH and of its new academic profile and ambitions. Ever since the journal's return, Jørgen Delman has been an active member of the editorial board, and we look forward to our collaboration in the years to come.

\section{REFERENCES}

Delman, Jørgen 1991. Agricultural Extension in Renshou County, China. A Case-Study of Bureaucratic Intervention for Agricultural Innovation and Change. Ph.D. dissertation, Aarhus University. Submitted 15 January 1991. R\&H Bulletin No. 28.

Delman, Jørgen 2021. 'Mit liv med Kina II (My life with China II)'. Kinabladet 86: 12-18. https://www.dansk-kinesisk.dk/kinabladet/. 